\title{
On Research of Non-governmental Applied Innovative Talents Cultivation Mode
}

\author{
Hao Yong \\ Department of Education \\ Xi'an Fanyi University \\ Xi'an, China
}

\begin{abstract}
During the transformation period of university and college, Talents Cultivation is the base, the core of country and ethnic and the key of development of the university. We should cultivate applied and innovation talents so that the position of the non-governmental university will be invincible. Four suggestions will be given : The definition of talent training mode, the construction of infrastructure, the optimization of professional optimum structure, the construction of teaching resource.
\end{abstract}

\section{Keywords — applied; innovation; talents cultivation}

\section{INTRODUCTION}

Talents cultivation is the basic work for the university. While, on the background of Public entrepreneurship, innovation, university should cultivate the applied innovative talents that must fit the needs of social economic development and can keep up with the times to meet the needs of the development of all walks of life and students' individual development .The universities cultivate the talents of all-round development who should have solid theoretical and broad knowledge, broadening vision, high comprehensive quality, strong innovative consciousness and practical ability. Nongovernmental university has unshrinkable responsibility to cultivate applied innovative talents because it is the most important department.

\section{APPLIED INNOVATIVE TALENTS AND CHARACTERISTIC}

\section{A. Applied Talents}

Applied talents is the technical and skilled talents who should serve the first line, such as production, service and management. At meanwhile, theory and practice are closely combined, the basic knowledge is solid, the skill level is higher, the skill can meet the requirement in all respects. The training of applied type talents is the new concept of running schools that is currently proposed by the private university, and is the inevitable choice for the sustainable development of the private colleges and universities.

\section{B. Innovative Talents}

About innovative talents, different scholars have different explanations. The benevolent see benevolence and the wise see wisdom. In the Innovation magazine, Innovation means to apply what you have already known to think out new methods, to establish new processes and to create new products. Some

The paper is sponsored by Xi'an Social Science Foundation Project (14XF010) others think that innovative talents should have Creative consciousness, creative thinking and creative ability. And so on

\section{Characteristic}

Innovation talents 'characteristic include creative ability, creative consciousness and creative personality. Creative ability means thinking creating, imaginative creating, strong sense of problem and reasonable knowledge structure. Creative consciousness include curiosity strong thirst for knowledge, interesting and motivation. Creative personality means strong achievement motivation, strong cooperation spirit, strong control ability, attitude and so on.

\section{QUESTION}

The key of development of college and university is the quality of education and teaching. Whether teaching's quality can be improved, it depends on the innovation of talents cultivation. "Now Chinese has not fully developed, an important reason is that no college or university can cultivate innovative talents in science and technology invention mode to go to school, does not have its own unique innovative things, always take the outstanding talents. This is a big problem." said Qian Xuesen, one of the most famous scientists in contemporary China.

\section{A. Backward Concepts}

Now , some teachers from leaders to the first-line managers is conservative, backward, not forward , and is almost stay at the origin, or an equal institution with other college and university, does not have innovation spirit, dare not to do "the first people eat crab", to keep the original limited outlook. How is teachers team built and the quality of the students improved if the leadership's thinking is limited? The thinking is more traditional and does something following the steps that have already done for many years.

\section{B. Unreasonable Curriculum Settings}

Professional setting is similar and has no distinguish features. Curriculum Settings have no choice and targeted. The theory and practice have no closely linked. The mode and method of teaching are mechanical, re-theory light practice, the heavy knowledge instilled the innovative spirit culture, the heavy professional education light comprehensive development That lead not to consistent the knowledge and skills of students with the needs of professional post in society. 
The theory is the main department of all curriculums, but the practice is the small part, sometimes ignored. The student's application can not be cultivated.

\section{The Teachers' Team not enough}

Teacher is dominant, and student is the main body in the class. So teachers should have innovative spirit. But some teachers are used to the current situation, not want to create new contents. They just want to finish their original tusk, to teach the same curriculum at every term. The teachers' positive and innovation can not be improve, the students are also more difficult. Some teachers have rich experience of theory, but have no practice for lacking of the experience of the first line. While others have practice experience, but no theory. The structure of teacher team is unreasonable. The younger teachers are the primary.

\section{EFFECTIVE METHOD}

Applied and innovative talents cultivation is the new school idea of the nongovernmental college and university, and is the main choice to lasting develop. So some effective methods are given to promote the development of the nongovernmental college and university.

\section{A. Renew Ideas}

Idea is the guider of behavior. So the leadership and management should renew their ideas to meet the needs of social development and to keep up with the times. Management, a unique concept, innovative thinking mode and dare to challenge, can train the team that is full of renewing ideas, innovative thinking and challenging.

\section{B. Perfecting the Structure of Specialty}

The college and university should have tier own advantages and features. During establishing the profession, they should have their main characters for avoiding to blind flowing. "No one I have, I have excellent." At the same, curriculum settings should be strengthened. Curriculum supports the talent training goals and specification. The theory and practice should be reasonably set. Some course' $s$ theory is more than practice, or not.

\section{Establishing a Applied Innovative Teachers' Team}

"The so-called great scholars, which are not meant to be buildings, are also known as masters." said Mei Yiqi, who is former President of Tsinghua university. In ancient times those who wanted to learn would seek out a teacher, one who could propagate the doctrine, impart professional knowledge, and resolve doubts. Where there is the doctrine, there is my teacher. Teacher should have basic and professional knowledge, practical knowledge. They should do some first-line task to build up the experience. They can teach the students' theory and practice knowledge to using abundant theoretical knowledge to guide practice. Teacher should go to the first line to learn practice experience for knowing how to combine theory with practice.

\section{CONCLUSION}

In a conclusion, applied innovation talents should be cultivated in the non-government undergraduate university and college during the transformation development period.
Because there are many problems to forbid the development of the non-government undergraduate university and college, such as, backward concept, unreasonable course and so on. Some suggestions are given to promote the applied innovation talents cultivation, for example, renewing concept, optimizing the professional structure, establishing a stronger teacher's team.

\section{REFERENCES}

[1] Yin Chongli, Liu Xunci,on the Training Model of Innovative Talents in College and University, Modern Enterprise Education,2008, pp167-169.

[2] Ma Dexiu, Looking for the breakthrough of talent training mode and cultivating innovative talents, China Higher Education,2013,pp20-21.

[3] Zhou Guangli, Deep exploration on the innovation of talent cultivation mode in Colleges and Universities, China Higher Education, 2015,pp2325.

[4] Wang Qinglin, Some thoughts on the training mode of Innovative Applied Undergraduate Talents, China University Teaching,2013,pp2225.

[5] Yan Meihong,The construction of Applied Innovative Talents Training Mode in general colleges ,Journal of Henan Vocation-Technical Teachers College(Vocational Education Edition),2015(11)pp8-10.

[6] Tang Junli, Yan Yongtao, Reflections on the cultivation mode of Applied English translation talents in newly established university, Western China Quality Education,2016,pp51-52. 